\title{
Influence of ecological Juniperus Drupacea cone powder on mechanical and physical properties of fiber-reinforced composite friction materials
}

\author{
Sait Aras', Harun Sepetcioglu ${ }^{2 *}$ \\ 'Selçuklu Vocational and Technical Anatolian High School, Department of Motor Vehicle Technology, Konya, 42070, Turkey, ${ }^{2}$ Selçuk University, Faculty \\ of Technology, Department of Metallurgy and Materials Engineering, Konya, 42075, Turkey
}

Orcid: S. Aras (0000-0003-26I8-535X), H. Sepetcioglu (0000-000I-5746-4234)

\begin{abstract}
This work is aimed to study the mechanical and physical properties of composite friction materials (CFMs) produced by using various fiber types (glass, carbon, and basalt) filled and unfilled Organic Juniperus Drupacea Cone Powder (JDCP). The CFMs were tested by using a pin-on-disc tribo-test-rig under dry contact conditions. The JDCP gradually reduced the density of CFMs. The surface hardness of the CFMs exhibited a decreasing trend with the addition of JDCP filler. The presence of JDCP within the CFMs considerably increased the water and oil absorption. The results showed that the JDCP filled and unfilled basalt fiber reinforced CFMs had higher friction coefficients than JDCP filled and unfilled glass and carbon fiber reinforced CFMs. In addition, the friction coefficient of filled and unfilled carbon fiber reinforced CFMs was found to be the lowest. The tensile strengths obtained from the indirect tensile (Brazilian) test of basalt, glass and carbon fiber reinforced test CFMs increased with JDCP filler. In addition, the tensile strength of JDCP filled and unfilled carbon fiber reinforced FCMs proved to have better wear resistance than all other CFMs. The wear resistance of basalt, glass, and carbon fiber reinforced CFMs decreased with the increase of JDCP wt.\% filler. Among JDCP filled and unfilled all CFMs, the highest wear resistance was detected in carbon fiber reinforced CFM. The minor wear resistance was seen in glass fiber reinforced CFMs than carbon and basalt reinforced samples.
\end{abstract}

Keywords: Fiber, Brazilian test, Organic Juniperus Drupacea, Wear, Hardness, Mass changes, Composite friction material

\section{Introduction}

Typical composite friction material (CFM) is produced by curing a polymeric binder, organic and/or inorganic components under heat and pressure[1-3]. The components' properties directly affect the mechanical, physical, and frictional performance of the final CFMs $[4,5]$. As well as organic and inorganic fillers, the CFMs can be added with reinforcing materials such as basalt, carbon, glass fiber $[2,6,7]$. When the percentage by weight of the components used in producing such multi-component composite materials is selected appropriately, the improved structural properties expected from the final product can be obtained $[6,8,9]$.

There has been a great deal of research in the literature to produce the CFMs used in industrial applications from various ecological and biological materials. According to the literature, the CFMs may be divided into three materials groups: reinforcement, binder, and filler[10-12]. In addition, some studies also accept friction adjusters, colourants, abrasives, lubricants, cleaners, and metallic fillers in material groups $[13,14]$. In many studies, barite was used as filler material, phenolic resin as the binder material, different fiber types as reinforcement material, cashew as friction adjuster, graphite and coke as a solid lubricant. Seashells [15], palm kernel shell [16], ulexite $[17,18]$ and pinus brutia $[18]$ cone powder, ground cow bone, larch cones and cashew powder [19], periwinkle shell [20], rubber [13], banana peels [21], larch, red pine, scotch pine, pine and cones of cedar trees [22], red pine cones [23], cashew powder [24-26] mussel, bone, animal hoof and animal horn powders [27], cashew nut shell liquid, flaxseed oil and palm kernel fibers [28] are organic fillers investigated for friction material.

Arman et al. examined the commercial CFM obtained by adding different agricultural wastes as an alternative to brake pads with asbestos. They stated that the performance of these examined CFM is similar to that of asbestos brake pads [29]. Binda et al. have produced slate particle reinforced phenolic composites, a new reinforcement for the CFM. They investigated the effect of the slate 


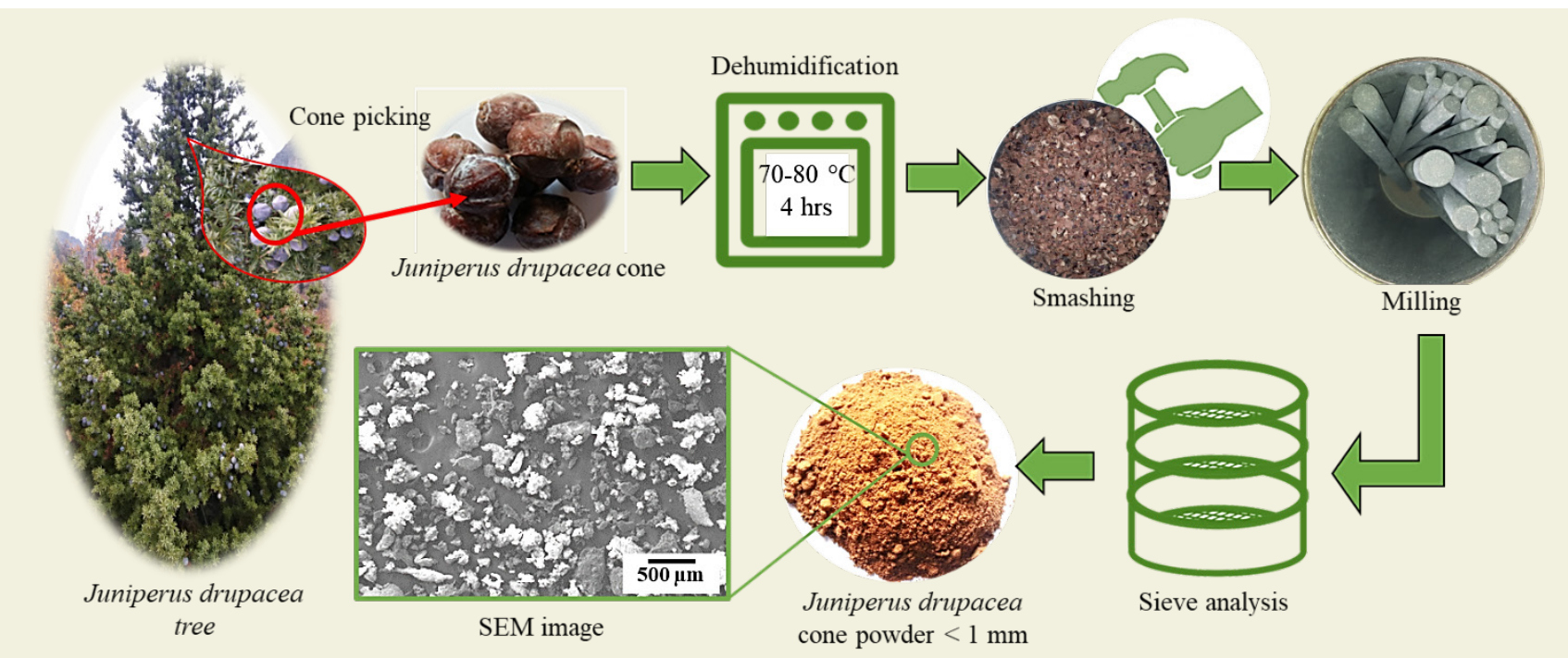

Figure 1. Illustration of the production stages of Juniperus Drupacea cones powder

ratio on the friction properties of the CFM. They stated that the friction coefficients of the composites produced are stable. In addition, they indicated that the $40 \mathrm{wt} . \%$ slate reinforced phenolic composite had tribological properties reaching those of commercial CFMs [30]. Finally, de Fazio et al. studied the abrasion resistance of hemp fibers and compared it to glass and carbon fibre-reinforced composites. They have observed that natural fibers such as hemp fibers exhibit better abrasion behaviors than synthetic fibers [7].

It is necessary to understand a CFM's basic material properties that act its task under conditions of abrasive, forcible impact and exposure to liquid. On this basis, this study's motivation is to investigate the usability of Juniperus Drupacea Cone Powder (JDCP), which is used to produce fruit concentrate in the food industry, as a friction material component. In the case of multi-component composites, it is known that the ratio of filler has a profound effect on the mechanical, wear, and physical properties of composite materials. However, no studies related to JDCP filled CFM in the literature except for the studies $[2,31,32]$ that Aras was involved in. Therefore, the purpose of this study is to investigate the effects on density, hardness, liquid absorption, wear resistance, friction coefficient, the tensile strength of JDCP filled CFMs. Furthermore, their features, which it gains to CFM due to the heterogeneous structural complexity of JDCP, are difficult to predict. In addition, an indirect tensile test approach is proposed to determine the tensile properties due to the brittle characteristic of JDCP filled CFMs.

\section{MATERIAL AND METHOD}

\section{I. Raw Materials}

In this study, barite, phenolic resin, coke, three different (glass, carbon, basalt) fibers, Organic Juniperus Drupacea Cone Powder were used to investigate the CFMs. The barite (particle size $5 \mu \mathrm{m}$ ) and phenolic resin were supplied from Barite Mining Turkish Inc and Çukurova Chemical Industry Inc., Glass fiber from Glass Fiber Industry Inc, Basalt fiber from Yuniu Fiberglass Manufacturing(Hebei) Co. Ltd, and Carbon fiber from Spinteks was purchased. Coke was produced from the Konya Technical University Mining Engineering laboratory. Juniperus Drupacea Cones were collected as the sun-dried from the Sariveliler region, Karaman city, Turkey. They were then ground in a rod mill to powder form. Afterward, the powder obtained was characterized using a sieve with mesh-size $(1.0 \mathrm{~mm})$ and resulted in powder size $\leq 1 \mathrm{~mm}$. The production stages of the Juniperus Drupacea Cone powder were given in Fig. 1 . The density values of the components of CFM provided by the producer are given in Table 1 .

Table I. The density value of the components used in the study

\begin{tabular}{cc}
\hline Components & Density, $\mathbf{g} / \mathbf{c m}^{3}$ \\
Glass fiber & 2.54 \\
Carbon fiber & $1.75-1.95$ \\
Basalt fiber & $2.65-2.80$ \\
JDCP & 0.906 \\
Barite & 4.25 \\
Coke & 1.4 \\
Resin & $1.18-1.23$ \\
\hline
\end{tabular}

\subsection{Preparation of Composite Friction Materials}

In order to produce the samples, the components specified in Table 2 were mixed in a double-blade mixer for $15 \mathrm{~min}$. Then they were molded at $160^{\circ} \mathrm{C}, 100 \mathrm{MPa}$ pressure for $15 \mathrm{~min}$ in a hydraulic. These production parameters optimized in the previous study [2] were employed in the current study. In addition, more detailed information about the production steps of powder and the hot pressing process was given in the previous studies $[2,32]$. The images of the hydraulic press and the externally heated mold used in production, and the codes of CFMs produced are given 
in Fig. 2. The sample coding was carried out considering fiber type and JDCP filler ratio by weight.

Table 2. The components of the CFMs (wt.\%)

\begin{tabular}{ccccccc}
\hline $\begin{array}{c}\text { Sample } \\
\text { Code }\end{array}$ & $\begin{array}{c}\text { Fiber } \\
\text { Type }\end{array}$ & JDCP & Barite & Fiber & Resin & Coke \\
\hdashline GF00 & GF & 0 & & & & \\
GF05 & GF & 5 & & & & \\
GFI5 & GF & 15 & & & \\
GF20 & GF & 20 & & & & \\
CF00 & CF & 0 & & & & \\
CF05 & CF & 5 & 50 & 20 & 25 & 5 \\
CFI5 & CF & 15 & & & & \\
CF20 & CF & 20 & & & & \\
BF00 & BF & 0 & & & & \\
BF05 & BF & 5 & & & \\
BFI5 & BF & 15 & & & \\
BF20 & BF & 20 & & & \\
GF:Glass fiber, CF:Carbon fiber, BF:Basalt fiber, JDCP: Juniperus Drupacea Cone \\
Powder
\end{tabular}

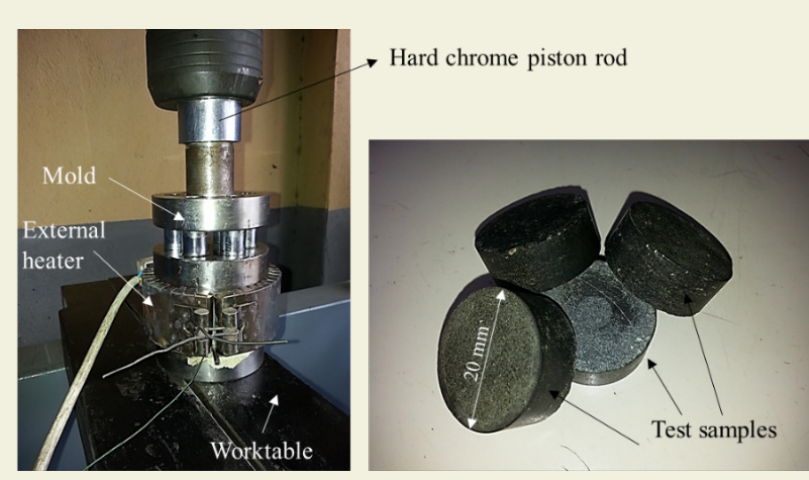

Figure 2. The images of the externally heated mold and the samples

\subsection{Mass changes}

The water and oil absorption of JDCP filled and unfilled CFMs were conducted following ASTM D 5229. Before the absorption test, the weight of each sample was measured in high precision digital scale balance with a resolution of 0.001g. Three samples of each type of CFMs were immersed in distilled water and oil at room temperature. The residual water and oil on the samples were cleaned and dried before weighing samples exposed to the liquid environment. Next, the weights of the sample were measured, and the mass changes were calculated. The mass measurements were taken frequently due to the relatively high absorption in the first 24 hours of the immersion period. After 24 hours, mass measurements were measured once every 24 hours and continued until each of the samples reached saturation. The mass change was calculated using the Eq. (1):

$$
M(\%)=\frac{\left[m_{f}-m_{i}\right]}{m_{i}} .100
$$

Where $m_{i}(g)$ and $m_{f}(g)$ are the mass of test samples before and after liquid immersion, respectively.

\subsection{Density Measurements}

The densities of the CFMs were determined with the Archimedean principle. In density measurements of CFMs, A digital caliper with $0.01 \mathrm{~mm}$ precision and Precisa XB220 precision balance were used. In order to avoid water absorption by CFMs during density measurements, weighing operations were carried out within $15 \mathrm{~s}$.

\subsection{Hardness Test}

For the hardness measurements of the CFMs, a universal hardness device was used. The hardness values of CFMs were taken in the Rockwell $\mathrm{R}$ scale $(1 / 2$ inch ball, $10 \mathrm{~N}$ preload, $60 \mathrm{~N}$ total load). The hardness measurements were repeated five times for each CFM.

\subsection{The Brazilian Test}

The Brazilian test is a simple indirect tensile test developed to determine the semi-static tensile strength of brittle material $[33,34]$. In this test method, a cylindrical sample is loaded as shown in Fig. 3, and stress $\left(\sigma_{\mathrm{yy}}\right)$ occurs in the vertical direction to the loading along the loaded diameter. The samples were loaded between two steel plates in a universal tensile tester. Herein, the load was formed along the $\mathrm{X}$-axis with two symmetrical lines (F/B, per unit thickness). The stress field does not occur homogeneously in the loaded sample [35-37]. The $\sigma$ values seen in Fig. 3 correspond to the $\sigma_{\mathrm{yy}}$ stress caused by the load $(F)$ affecting the plane $(y=0)$ in the sample centre. Actually, stress is much greater at points in this plane, except for the points $X= \pm R$. During the test, final failure occurs vertically due to the direction of the tensile stresses [37]. The Brazilian test method, a quasi-static test, was preferred to samples to detect the response in the strength of CFMs exhibiting a brittle character. This method can be applied to the materials that behave completely elastic and present shear and compression strengths greater than their tensile strength. Brazilian tests performed were carried out under compression load $1.0 \mathrm{~mm} / \mathrm{min}$ according to ISRM (1981) and TS 7654 (1989) standards [23, 34]. Eq (2) was used to calculate the indirect tensile strength $\left(\sigma_{y}\right)$ of the samples:

$$
\sigma_{\mathrm{y}}=\frac{2 \mathrm{~F}}{\pi \mathrm{DB}}
$$

Where $\sigma_{\mathrm{y}}$; the indirect tensile strength, F; load, D; diameter of the test sample, B; width of the test sample.

\subsection{Wear Test}

Wear tests were carried out in a Pin-on-disc type tribo-test machine with a rotary motion, as shown in Fig. 4. Considering the available studies in the literature [38-40] and TS 9076 standard, wear tests were employed at 700 rpm, $1050 \mathrm{kPa}$ pressure, and $10000 \mathrm{~m}$ sliding distance parameters. The abrasive disc used in the abrasion test is made of Gray cast iron and has an average diameter and hardness of $180 \mathrm{~mm}$ and $197 \mathrm{HB}$, respectively. Prior to 


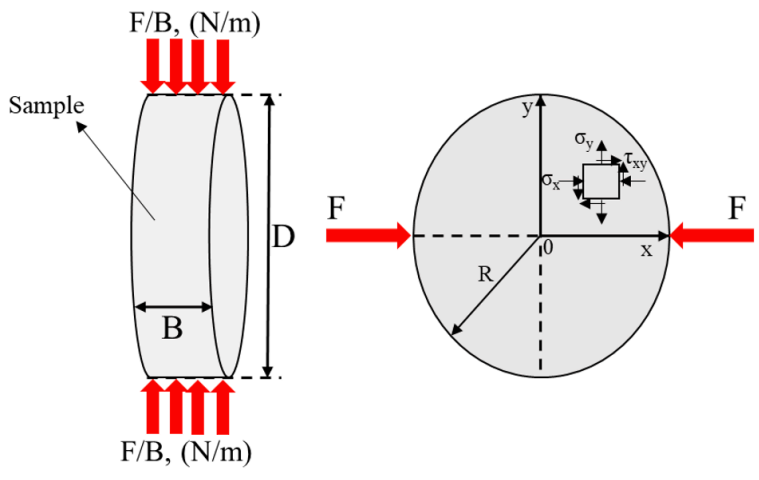

Figure 3. Illustration of the Brazilian test

the test, different abrasive discs, which are ground, were used for each specimen. Before and after the abrasion test, the sample masses were measured using a precision scale, and the found mass change amounts $\left(\mathrm{m}_{1}-\mathrm{m}_{2}=\Delta_{\mathrm{m}}\right)$ were used to calculate the wear rates $\left(\mathrm{W}_{\mathrm{a}}\right)$ of the samples. The wear tests were repeated three times for each sample. The average values obtained from the test results were used to calculate the wear resistance and friction coefficient. Thus, Eq (3) and Eq (4) were used to calculate the samples' wear amount and wear resistance.

$$
\begin{aligned}
& W_{a}=\frac{m_{1}-m_{2}}{m_{1}} \times 100 \\
& W_{r}=\frac{1}{W_{a}}
\end{aligned}
$$

$\mathrm{W}_{\mathrm{a}}$; the amount of wear, $\mathrm{W}_{\mathrm{r}}$; wear resistance, $\mathrm{m}_{1}$; sample mass $(\mathrm{g})$ before the test, $\mathrm{m}_{2}$; sample mass $(\mathrm{g})$ after the test.

As shown in Fig. 4, the friction coefficient $(\mu)$ values were calculated with Eq. (5) by using the $\mathrm{M}_{2}$ load values transferred from the load cell on the test device to the computer in the wear tests performed under the $\mathrm{M}_{1}$ load applied.

$$
\mu=\frac{L_{1} \cdot M_{2}}{L_{0} \cdot M_{1}}
$$

Where, $\mu$; friction coefficient, $\mathrm{L}_{1}$; distance between moment center and load cell (mm), $\mathrm{M}_{1}$; applied load (g), $\mathrm{L}_{0}$; distance between moment center and applied load $(\mathrm{mm})$, $\mathrm{M}_{2}$; load read from the loadcell. The wear resistance and amounts were calculated from Eq. (3) and Eq. (4) and presented in Table 3.

\subsection{Scanning Electron Microcopy (SEM) Examination}

All the samples and JDCPs were pinned on aluminium stubs, sputter-coated with gold (Cressington sputter coater 108$)$ at $5-7 \mathrm{~nm}$ thickness at $0.18 \mathrm{mbar}$, and observed under a scanning electron microscope (Zeiss Evols10) under accelerating voltage of $30 \mathrm{~kW}$.

\section{RESULTS AND DISCUSSIONS}

\section{I. Water and Oil Absorption Properties}

The fiber-reinforced polymer composites based on nature fillers are sensitive to the liquid environment. So, the mechanical properties and dimensional stability of these composites are adversely affected by liquid contact. The mass changes in water absorption at different fiber and filler loading levels are given in Fig. 5 and Fig. 6.

Among all test samples, the mass change in GF20, CF20, and BF20 samples increased gradually at the first $24 \mathrm{hrs}$
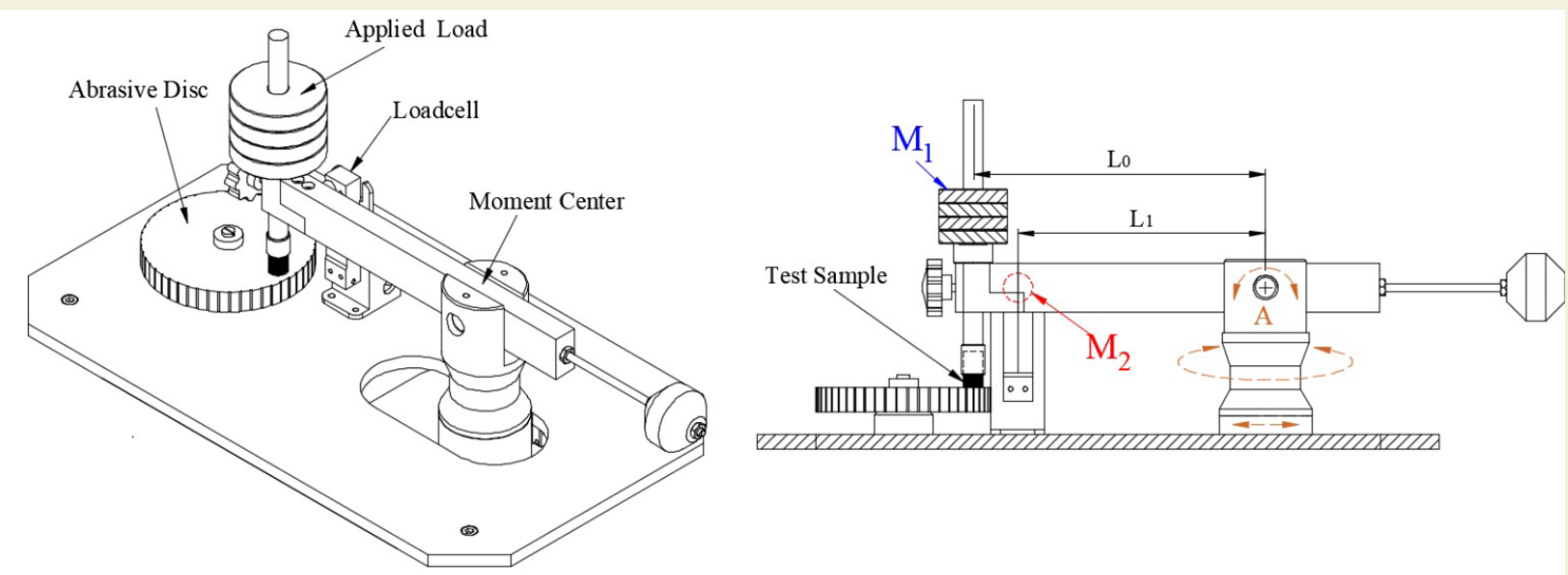

\begin{tabular}{|c|c|c|c|c|c|c|c|c|}
\hline $\begin{array}{l}\text { Sample } \\
\text { Codes }\end{array}$ & $\begin{array}{l}\text { Wear resistance } \\
\text { Wr, x107 }\end{array}$ & $\begin{array}{c}\text { Wear amounts } \\
\text { Wa, \% }\end{array}$ & $\begin{array}{l}\text { Sample } \\
\text { Codes }\end{array}$ & $\begin{array}{c}\text { Wear resistance } \\
\text { Wr, x } 107\end{array}$ & $\begin{array}{c}\text { Wear amounts } \\
\text { Wa, \% }\end{array}$ & $\begin{array}{l}\text { Sample } \\
\text { Codes }\end{array}$ & $\begin{array}{c}\text { Wear resistance } \\
\text { Wr, x } 107\end{array}$ & $\begin{array}{c}\text { Wear amounts } \\
\text { Wa, \% }\end{array}$ \\
\hline GF00 & 15.74 & 0.1359 & CFOO & 20.49 & 0.0937 & BF00 & 18.72 & 0.1248 \\
\hline GF05 & 15.26 & 0.1403 & CF05 & 17.61 & 0.0978 & BF05 & 16.05 & 0.1302 \\
\hline GFI5 & 13.82 & 0.1332 & CFI5 & 16.43 & 0.1093 & $\mathrm{BFI5}$ & 14.70 & 0.1314 \\
\hline GF20 & 12.63 & 0.1471 & CF2O & 15.76 & 0.1132 & $\mathrm{BF} 20$ & 13.80 & 0.1407 \\
\hline
\end{tabular}

Figure 4. Pin-on-disc type tribo-test machine[2]

Table 3. Wear resistance and amounts calculated from Equation 3 and Equation 4 

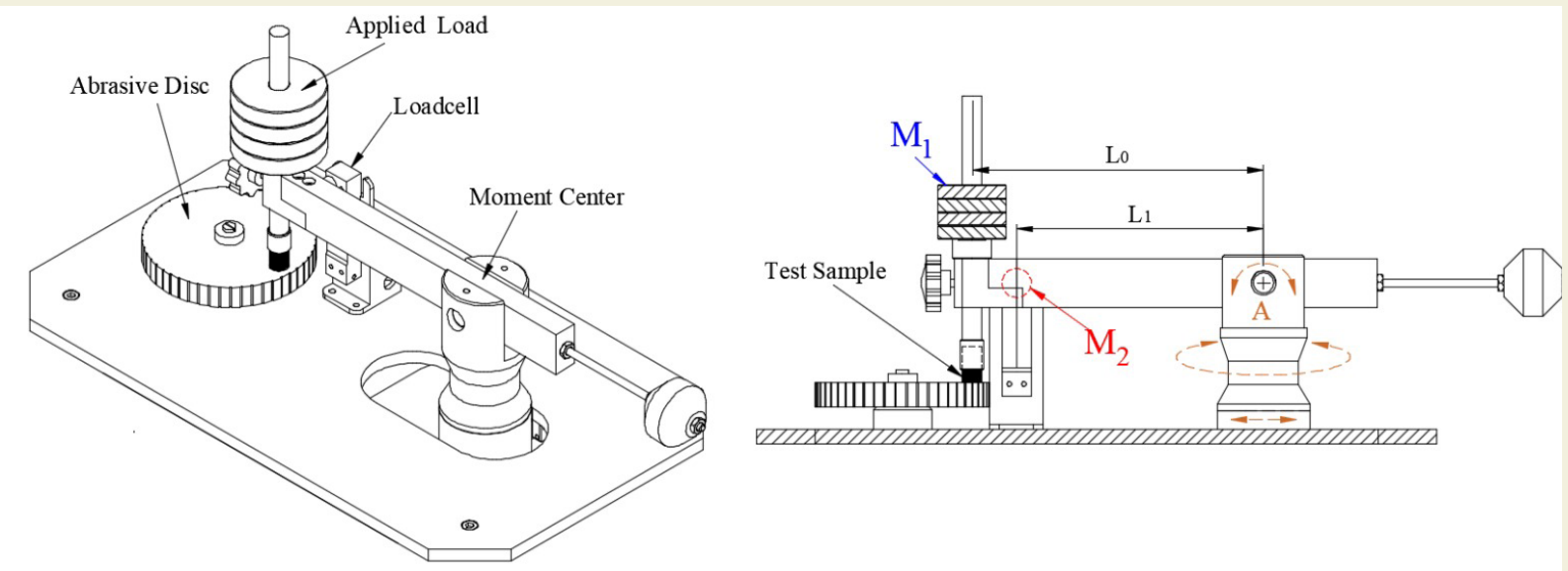

Figure 4. Pin-on-disc type tribo-test machine[2]
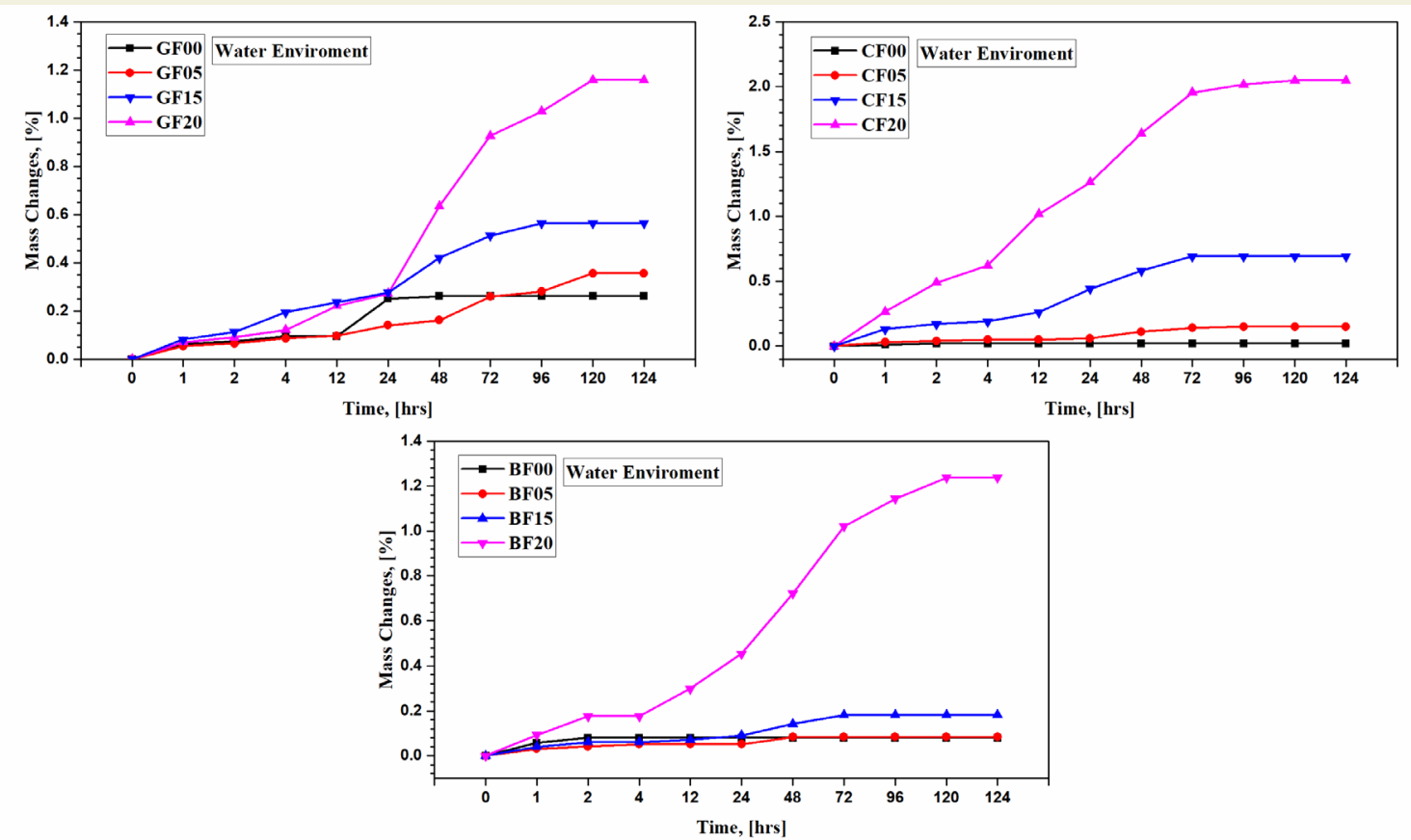

Figure 5. Mass changes in the water environment of JDPE filled glass, carbon, and basalt fiber reinforced polymer composite as a function of time
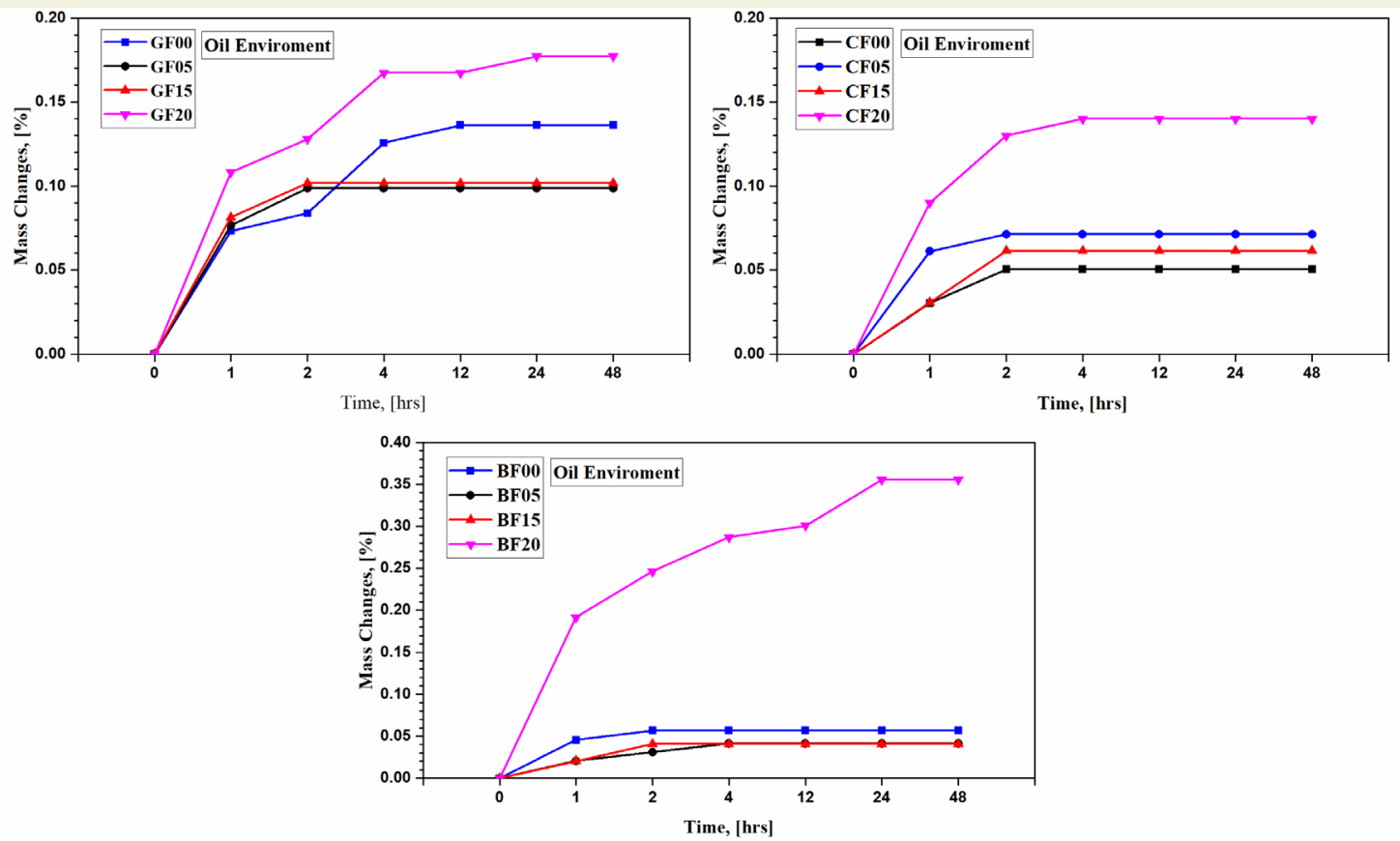

Fig. 6 Mass changes in the oil environment of JDPE filled glass, carbon, and basalt fiber reinforced polymer composite as a function of time 
of absorption and then tremendously increased until saturation was reached after $124 \mathrm{hrs}$ immersion in distilled water. The addition of JDCP within the glass, carbon, and basalt fiber reinforced polymer composite considerably increased the water uptake. The mass change in the CF00 sample remained in the range of $0-0.1 \%$. Hence, it was determined that the CF00 sample was the most insensitive to the water environment in the 124-hrs immersion period compared to the other samples. This suggests that CF00 has the resistance to water uptake than GF00 and BF00 due to the hydrophobic nature of carbon [41]. As the JDCP loading rate increases, water uptake of the glass, carbon, and basalt fiber reinforced samples has ascended, as shown in Fig. 5.

The mass changes in oil absorption at different fiber and filler-loading levels are presented in Fig. 6. In contrast to the aquatic environment, all test specimens reached saturation after $48 \mathrm{hrs}$ immersion in oil. In contrast to the water environment, GF20 and BF20 samples reached saturation at $24 \mathrm{hrs}$ of oil immersion. The CF20 sample reached saturation $4 \mathrm{hrs}$ after the immersion. Thus, the CF20 sample of water uptake rate was found to be higher than all samples in the oil environment. This can be associated with the interfacial voids between the carbon fibers and the JDCP and the voids between the barite, coke, and resin, which can uptake the water.

Similar to the water environments, as the JDCP \% loading rate increases, oil uptake of the glass, carbon, and basalt fiber reinforced samples has risen, as shown in Fig. 6 . On the other hand, the mass change in the BF00 sample remained in the range of $0-0.5 \%$. Thus, it was detected that the BF00 sample was more insensitive to the oil environment in the 4-hrs immersion period than the GF00 and CF00 samples. Consequently, as the JDCP loading rate increased, the water and oil absorption increased significantly. This can be attributed to the increased porosity rate, which is dependent on the decrease in density of JDCP filled composite materials, as shown in Fig 8a. In addition, these composites' $s$ water uptake of reason can be associated due to the high moisture capability of $\mathrm{J}$. drupacea fruits [42]. These liquid absorptions, which increased with the addition of different fiber reinforcement and filler, can be one of the biggest obstacles to expanding using polymer composites in industrial applications.

\subsection{Friction and Wear}

The friction coefficient is affected by temperature, pressure (load), and sliding velocity [43]. Therefore, these parameters were pegged constant in friction tests. During the wear test, the effects of JDCP filler rates on the friction coefficient according to distance were given in Fig. 7. In addition, the value of friction coefficients during the wear tests is given in Table 4 at various sliding distances such as $250 \mathrm{~m}, 1000 \mathrm{~m}, 5000 \mathrm{~m}$, and $10000 \mathrm{~m}$. Among the $0 \mathrm{wt}$. \%, 5 wt. \%, 15 wt. \%, 20 wt. \% JDCP filled samples; the average friction coefficient was the highest in the samples with basalt fiber and the lowest in the samples with carbon fiber. The decrease in the friction coefficient of carbon fiber reinforced CFMs as the JDCP ratio increases can be attributed to the presence of lipid in JDPC. Akinci et al. [38] investigated the nutritional properties of Juniperus drupaceous fruits and reported that the fruit contains about $4.3 \%$ lipid. It is well known that carbon-based filler materials act as solid lubricants in CFM. Therefore, the friction coefficient of filled and unfilled carbon fiber reinforced CFMs is lower than the other samples can be explained by the lubricating effect of the carbon fiber and the lipid.

The found results are not consistent with the wear test results of $75 \mathrm{wt} . \%$ glass and $25 \mathrm{wt} . \%$ carbon fiber reinforced friction material conducted by Demir et al.[14]. The reason for this difference may be the coke and barite contained in the samples. On the other hand, our result is consistent with the average friction coefficients of CFMs made of basalt fiber, glass fiber, barite, and graphite produced by Moses et al. [44]. The friction coefficient increased slightly in glass, basalt, and carbon fiber reinforced samples as the ratio of JDCP increased. The tough JDCPs in CFMs may cause more extensive plastic deformation during sliding due to surface roughness-morphology and hardness interaction. The reduction of the adhesion between the matrix and the particle reduces the friction coefficient, but in this study, the friction coefficient of CFMs increased as reported in Ref [45]. Thus, JDCP filler may be used as friction-enhancing material in commercial CFMs. A constant and high coefficient of friction is required for the use of CFMs in commercial implementations [46].

Table 4. Average values for the friction coefficient and sliding distance

\begin{tabular}{|c|c|c|c|c|c|c|c|c|c|c|c|c|}
\hline \multirow{2}{*}{$\begin{array}{l}\text { Sliding dis- } \\
\text { tance }(\mathrm{m})\end{array}$} & \multicolumn{12}{|c|}{ Friction coefficient } \\
\hline & GF00 & GF05 & GFI5 & GF20 & CFOO & CF05 & CFI5 & CF2O & BFOO & BF05 & BFI5 & BF20 \\
\hline 250 & 0.18 & 0.18 & 0.18 & 0.18 & 0.16 & 0.16 & 0.17 & 0.17 & 0.18 & 0.18 & 0.18 & 0.20 \\
\hline 1000 & 0.18 & 0.18 & 0.20 & 0.20 & 0.15 & 0.14 & 0.15 & 0.15 & 0.18 & 0.20 & 0.19 & 0.23 \\
\hline 5000 & 0.17 & 0.19 & 0.18 & 0.20 & 0.13 & 0.11 & 0.12 & 0.13 & 0.18 & 0.21 & 0.20 & 0.21 \\
\hline 10000 & 0.14 & 0.17 & 0.17 & 0.19 & 0.14 & 0.11 & 0.11 & 0.11 & 0.17 & 0.19 & 0.21 & 0.17 \\
\hline
\end{tabular}


When different cones were added to 8 wt. \% copper, 5 wt.\% brass shavings, and $5 \mathrm{wt} . \%$ aluminum filled CFMs investigated in Ref [22], the friction coefficients were found between 0.26-0.31. In addition, Aras [47] stated that the friction coefficient of JDCP doped CFMs increased to 0.3 with the addition of $10 \mathrm{wt}$. \% bronze powder. We suggest that the main reason for the increase in the friction coefficient in CFMs to 0.28 is not due to cones but from various metal powder additions. In addition, the absence of metal powder in the CFMs examined in this study is the main reason for the friction coefficient lower than about 0.3 .

\subsection{Density and Hardness}

The densities of JDCP filled CFMs are given in Fig. 8a. The average density of the JDCP is $0.906 \mathrm{~g} / \mathrm{cm}^{3}$. As expected, the density of CFMs produced decreased due to the low density of the JDCP. Also, It was observed that as the JDCP ratio increased, the density of CFMs decreased gradually. The surface hardness of CFMs is shown in Fig 8b. A decreasing trend was detected in the hardness of all CFMs. However, compared to the carbon and glass fiber reinforced samples, it was observed that the percentage of hardness decrease was more remarkable as the rate of JDCP increased in basalt fiber reinforced samples.

\subsection{Brazilian Test}

Stress-strain curves for JDCP filled samples were presented in Fig. 9. Indirect tensile test results used for brittle materials are given in Fig. 9. The tensile strength of JDCP unfilled (Coded GF00, CF00, and BF00) CFMs was higher than all JDCP filled samples. For all fiber types, the tensile strength decreased as the JDCP ratio increased. These results may be explained by the relatively low tensile strength of JDCP, considering mechanical properties obtained on $1 \mathrm{wt} . \%, 5 \mathrm{wt} . \%$ and $10 \mathrm{wt} . \%$ JDCP filled epoxy

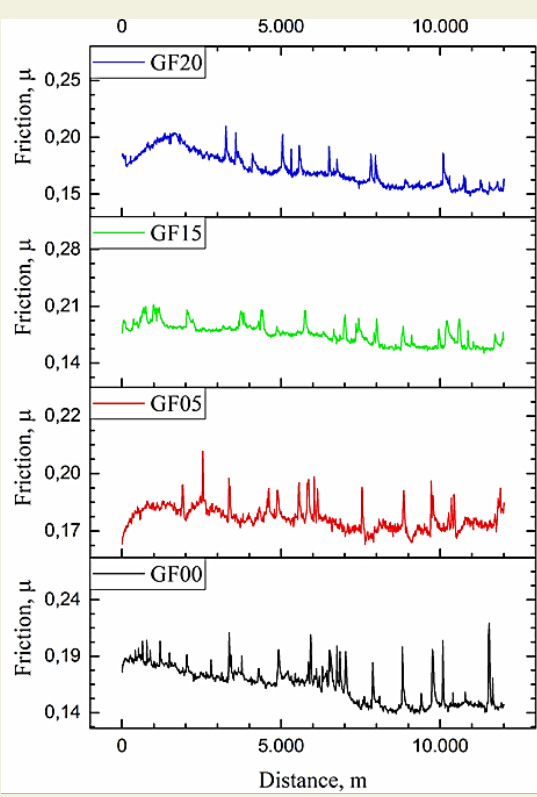

(a)

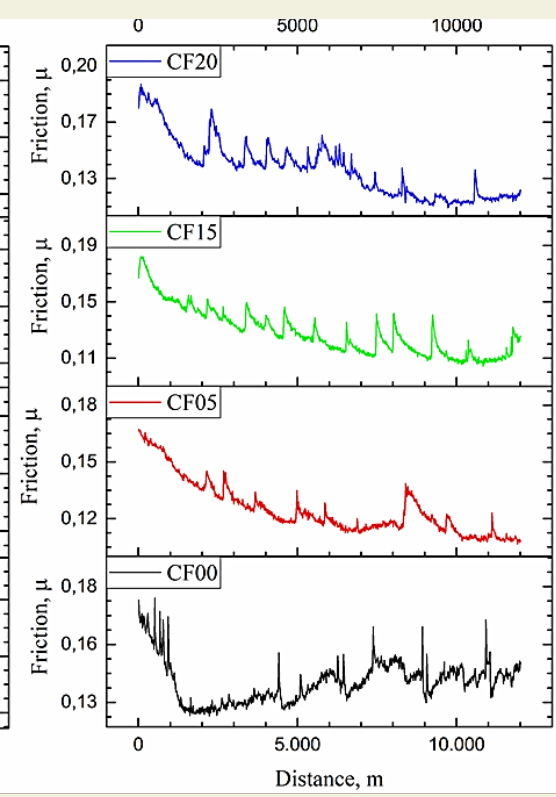

(b)

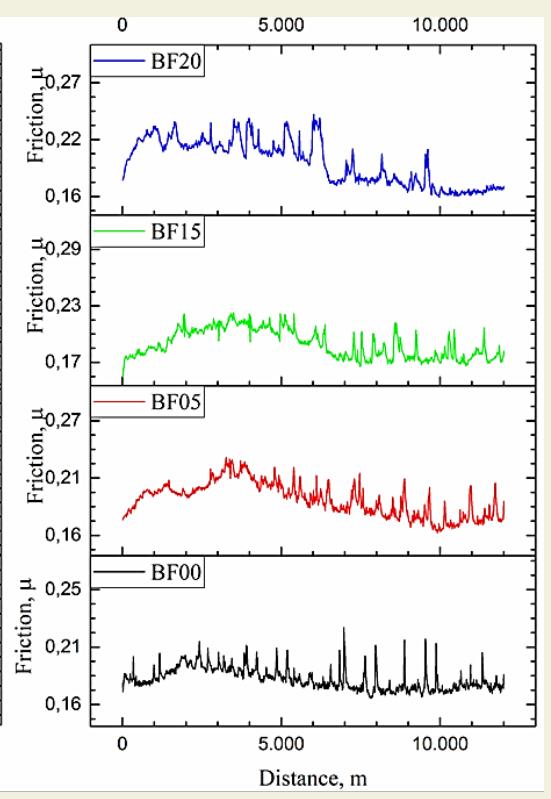

(c)

Figure 7. The friction coefficient-distance curves of JDCP filled samples; (a) glass fiber (GF), (b) basalt fiber (BF), (c) carbon fiber (CF)
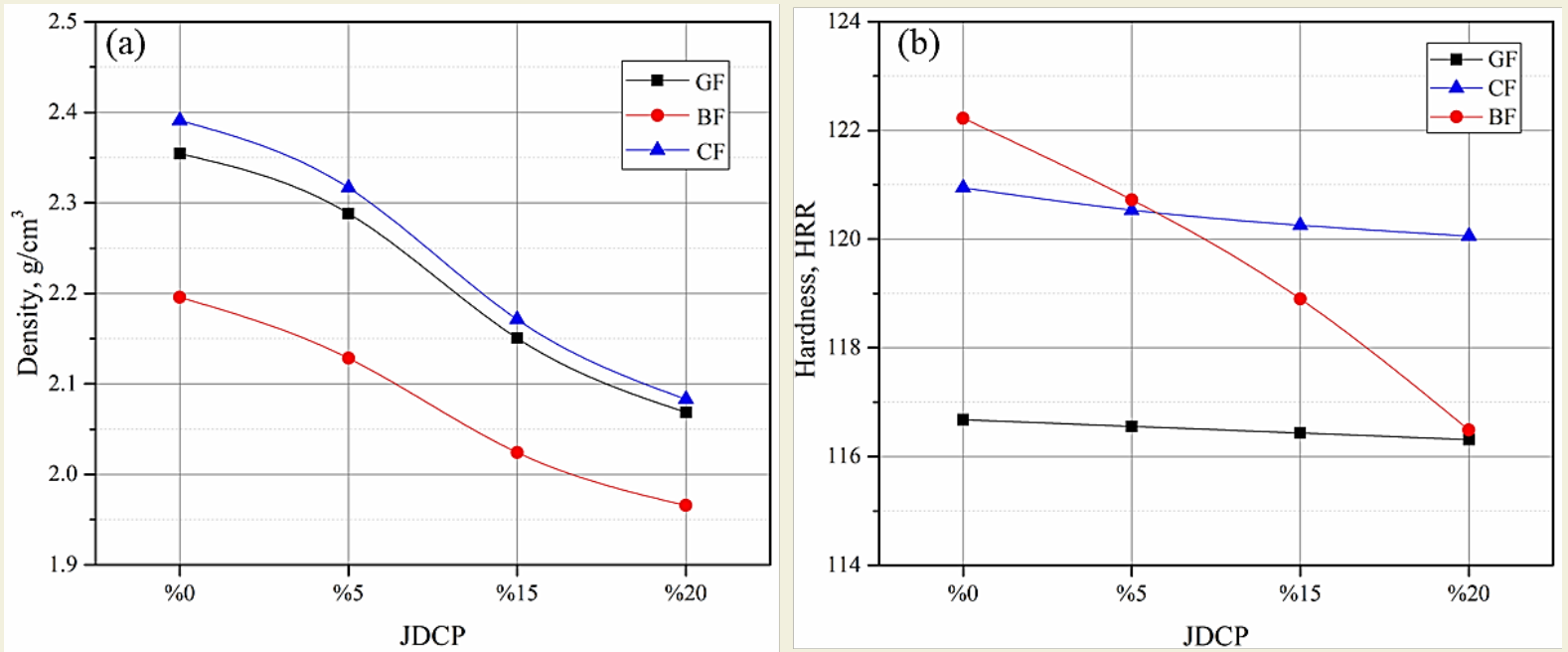

Figure 8. The density (a) and hardness (b) variations depending on JDCP content in the CFMs 
composites produced by Tasyurek and Aras [31]. The effects of fiber types on tensile strength in all JDCP filling ratios are given in Fig. 10b. Compared to glass and carbon fiber reinforced samples, the tensile strength of carbon fiber reinforced samples was the highest. The lowest tensile strength was obtained in glass fiber reinforced samples.

The difference in tensile strength between the JDCP filled and the $10 \mathrm{wt} . \%$ lipid existence can explain unfilled CFMs in the JDCP filler. The lipid-induced connection weakness between in-active JDCP and CFM components is thought to reduce the tensile strength of JDCP filled CFMs compared to the samples coded GF00, CF00, and BF00. With the increase in the JDPC ratio, the coke content of CFMs decreased from $5 \mathrm{wt} . \%$ to $4 \mathrm{wt} . \%$. The decrease in the coke additive in the CFMs content, as shown in Table 2, may be expressed as other reasons for the decrease in tensile strength. In a further study, microstructural characterization can be implemented to comprehend better the effect mechanism of JDCP filler on the strength development of CFMs.
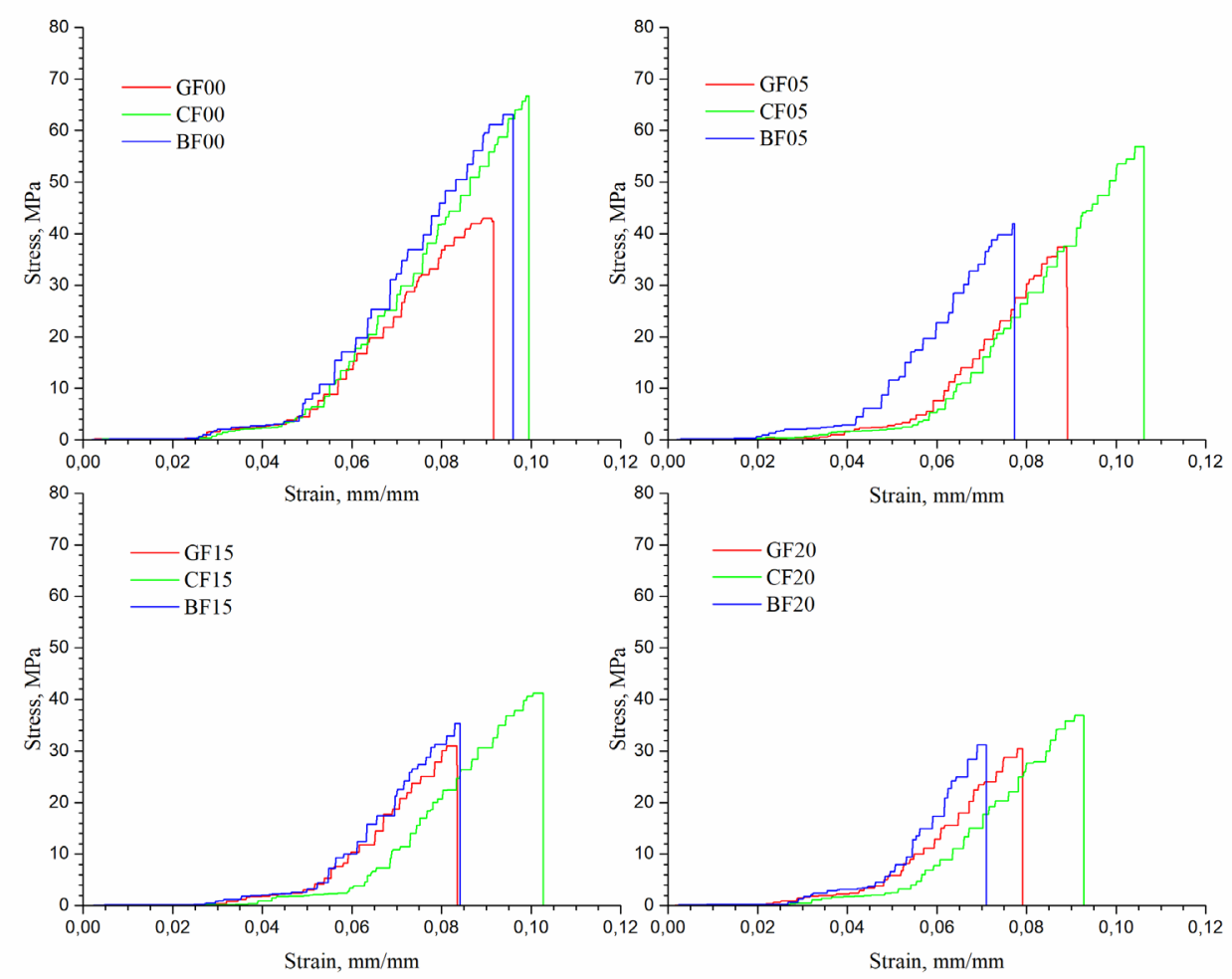

Figure 9. Indirect tensile (Brazilian) test results
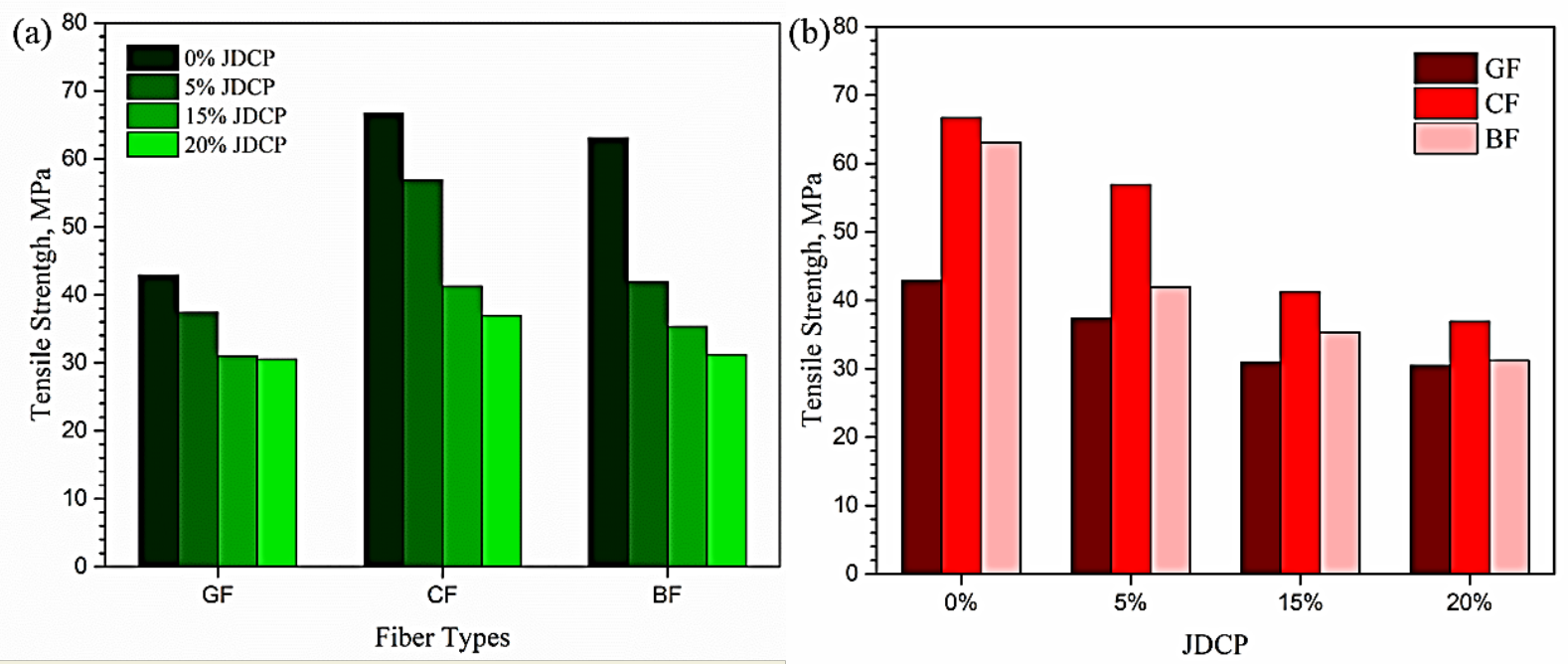

Figure 10. The indirect tensile strength of samples versus (a) fiber types, (b) JDCP filler ratio 


\subsection{SEM Examinations}

Fig. 11 shows SEM images of the $20 \mathrm{wt} \%$ JDCP filled CFMs at 500x and 100x magnifications after the wear test. The homogeneous distribution of fibers was determined from the SEM images. In the SEM images presented in Fig. 11b, Fig. 11d and Fig. 11f, wear marks that indicate the adhesive wear on the worn surfaces of the CFMs were detected. The worn surface of GF20 samples was significantly disrupted due to lower wear resistance (Fig. 11a). The heat generated during the wear test weak- ens the bond between fiber/phenolic resin [48]. In Figures 11a, 11c and 11e, it was observed that there were broken fibers and pull-out. The pits and hills formed on the contact area during the wear formed the dominant topographic appearance. The accumulation of broken fibers and JDCP-containing wear debris in these pits can lubricate the worn interface, resulting in a relatively lower coefficient of friction. In addition, any cracks were not observed in SEM images of CFMs. The possible a crack can grow into the wear surface; thus, it may cause spalling failure during
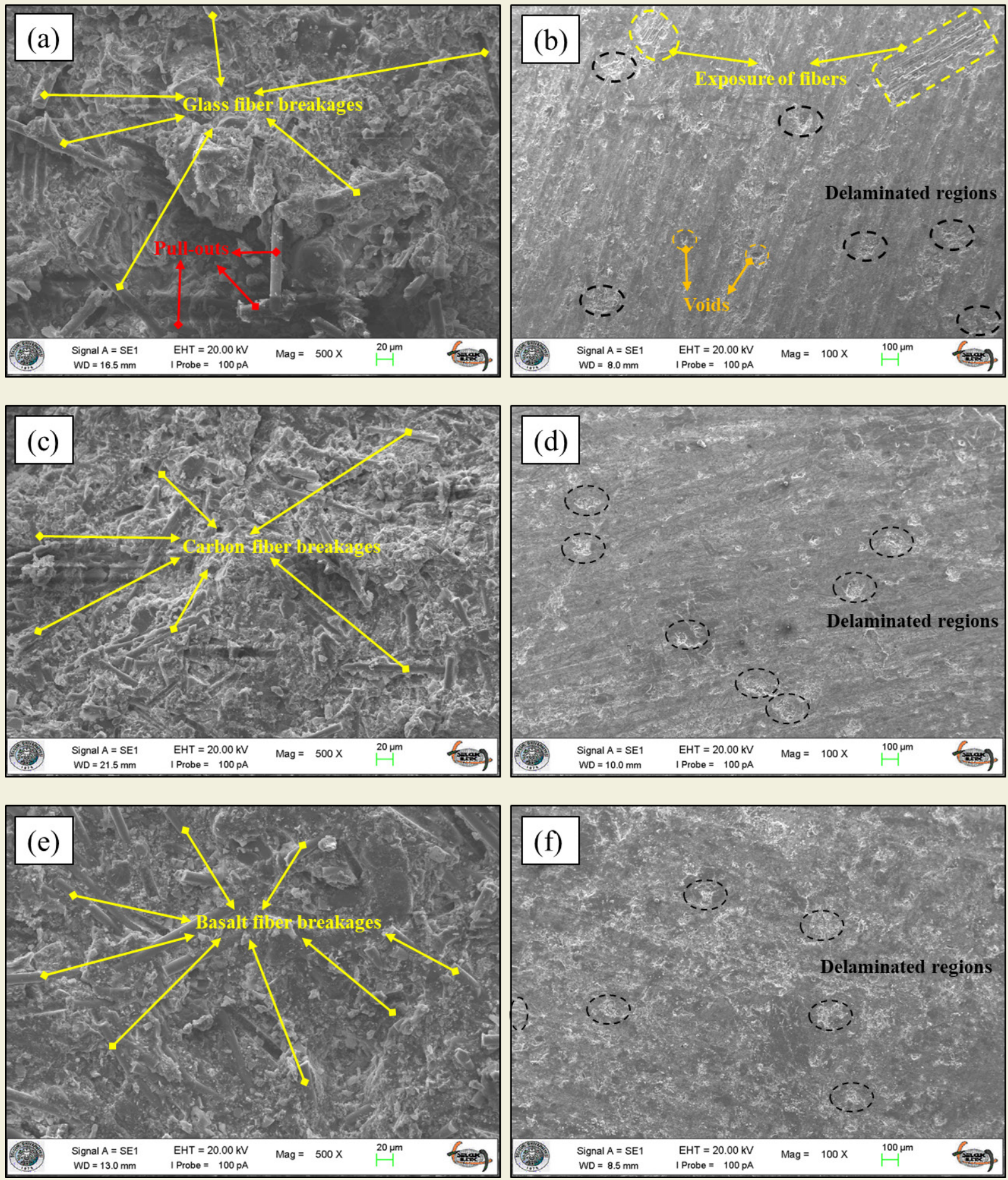

Figure 11. SEM images of the worn surfaces of CFMs at various magnifications of $20 \mathrm{wt}$. \% JDPC filled glass fiber reinforced (a and b), carbon fiber reinforced ( $c$ and $d$ ) and basalt fiber reinforced (e and $f$ ) 
the wear.

\section{Conclusions}

In this study, the effect of Juniperus Drupacea Cone Powder (JDCP) on mechanical and physical properties of composite friction materials (CFMs) produced by using various fiber types (glass, carbon, and basalt) has been experimentally studied.

The density of CFMs decreased gradually with the addition of JDCP. It was found that as the JDCP loading rate within CFMs increased, the water and oil absorption increased significantly. The friction coefficients of the CFMs obtained with the addition of JDCP increased slightly with the addition of JDCP. The friction coefficient of CFMs used in basalt fiber is higher than that of carbon and glass fiber. It was observed that the stability of the friction coefficient of JDCP filled CFMs enhance compared to unfilled CFMs. As the JDPC ratio increased, the surface hardness of CFMs containing glass, carbon, and basalt fibers decreased. In applications where the low hardness of CFMs is aiming, the JDCP can be employed to reduce their hardness. The wear resistance and tensile strength decreased with the addition of JDCP. It was detected that there is a parallelism between the wear resistance and tensile strength. The SEM studies revealed the wear failures in the wear surface of the CFMs. Except for low wear resistance, the usage of JDCP as filler in CFMs presents the combination of desired properties of CFMs. Thus, it indicated the considerable potential to replace the commercially used fillers. In addition, the laboratory-scale powder preparation showed the cost of production of the JDCP would be reasonable. However, in-depth works must be planned to make cost study in industrial conditions.

\section{References}

[1] Majeed, B., Basturk, S. (2020). Analysis of polymeric composite materials for frictional wear resistance purposes. Polymers and Polymer Composites, DOI: 0967391120903957.

[2] Aras, S., Tarakçıoğlu, N. (2021). Optimization and assessment of brake pad production parameters and organic Juniperus drupacea cone powder additive ratio using the Taguchi method. Journal of Composite Materials, DOI:0021998321997532.

[3] Sepetcioglu, H. (2021). Characterization of Mechanical of CTBN Liquid Rubber-Modified Epoxy Cured by Anhydride-and Amine-Based Agent. European Mechanical Science, 5(3):121-9.

[4] Kolluri, D., Ghosh, A., Bijwe, J. (2010). Performance evaluation of composite friction materials: Influence of nature and particle size of graphite. Journal of Reinforced Plastics and Composites, 29(18): 2842-54.

[5] Xu, X., Lu, X., Qin, Z., Yang, D. (2017). Influence of silica as an abrasive on friction performance of polyimide-matrix composites. Polymers and Polymer Composites, 25(1): 438.
[6] Cheng, B., Kortschot, M. (2016). A Study of the Friction Coefficients of Unidirectional and Woven Carbon Fibre/ Epoxy Composites. Polymers and Polymer Composites, 24(4):255-63.

[7] De Fazio, D., Boccarusso, L., Durante, M. (2020). Tribological Behaviour of Hemp, Glass and Carbon Fibre Composites. Biotribology, 21: 100113.

[8] Etemadi, H., Shojaei, A., Jahanmard, P. (2014). Effect of alumina nanoparticle on the tribological performance of automotive brake friction materials. Journal of Reinforced Plastics and Composites, 33(2): 166-78.

[9] Unaldi, M., Kus, R. (2017). The effect of the brake pad components to the some physical properties of the ecological brake pad samples. In IOP conference series: materials science and engineering, 191(1): 012032

[10] Dönmez, A. (2000). Asbest Dışı Elyaflarla Üretilen Balata Malzemelerinin Özelliklerinin İncelenmesi. Doktora tezi, Karadeniz Teknik Üniversitesi, Trabzon.

[11] Gümüş, E. (2012). Otomotivde Kullanılan Kompozit Sürtünmeli Fren Balatalarında Yerli Uçucu Kül Katkısının Balata Özelliklerine Etkisinin İncelenmesi. Yüksek Lisans Tezi, Yıldız Teknik Üniversitesi, İstanbul.

[12] Öztürk, B., Arslan, F., Öztürk, S. (2007). Hot wear properties of ceramic and basalt fiber reinforced hybrid friction materials. Tribology International, 40(1):37-48.

[13] Baklouti, M., Cristol, A-L., Desplanques, Y., Elleuch, R. (2015). Impact of the glass fibers addition on tribological behavior and braking performances of organic matrix composites for brake lining. Wear, 330:507-14.

[14] Demir, M. E., Çelik, Y. H., Kılıçkap, E. (2019). Cam ve Karbon Elyaf Takviyeli Kompozitlerde Elyaf Cinsinin, Yükün, Kayma Hızı ve Mesafesinin Abrazif Aşınmaya Etkisi. Politeknik Dergisi, 22(4): 811-817.

[15] Abutu, J., Lawal, S., Ndaliman, M., Lafia-Araga, R., Adedipe, O., Choudhury, I. (2018). Effects of process parameters on the properties of brake pad developed from seashell as reinforcement material using grey relational analysis. Engineering Science and Technology, an International Journal, 21(4), 787-797.

[16] Afolabi, M., Abubakre, O., Lawal, S., Raji, A. (2015). Experimental investigation of palm kernel shell and cow bone reinforced polymer composites for brake pad production. International Journal of Chemistry and Materials Research, 3(2):27-40.

[17] Sugözü, B. (2019). Friction and Wear Behavior of Fiber Reinforced Polymer-Matrix Composites Containing Ulexite and Pinus Brutia Cone Dust. European Mechanical Science, 3(3):92-6.

[18] Sugözü, l., Kahya, K. (2018). Investigation of the Effect on Tribological Properties of the use of Pinus Brutia Cone as a Binder in Brake Pads. European Mechanical Science, 2(4):115-8.

[19] Akpınar, G. (2008). Modifiye Edilmiş Karaçam Kozalaklarının Otomotiv Fren Balatalarında Kullanımının Araştırılması. Yüksek Lisans Tezi, Afyon Kocatepe Üniversitesi, Afyon.

[20] Amaren, S., Yawas, D., Aku, S. (2013). Effect of periwinkles shell particle size on the wear behavior of asbestos free brake pad. Results in Physics, 3:109-14. 
[21] Idris, U., Aigbodion, V., Abubakar, I., Nwoye, C. (2015). Eco-friendly asbestos free brake-pad: Using banana peels. Journal of King Saud University-Engineering Sciences, 27(2):185-92.

[22] Kahya, K. (2017). Otomotiv Fren Balatalarında Farklı Bağlayıcı Malzeme Kullanımının Frenleme Performansına Etkisinin Araştırılması. Yüksek Lisans Tezi, Mersin Üniversitesi, Mersin.

[23] Sugözü, B. (2016). Nano silika, nano alümina ve nano zirkon aşındırıcı parçacık katkısının fren balata özelliklerine etkisi. Fen Bilimleri Enstitüsü Doktora Tezi, Konya.

[24] Kara, F. (2011). Karbon Elyaf Takviyeli Otomotiv Fren Balata Özelliklerinin Araştırılması. Yüksek Lisans Tezi, Afyon Kocatepe Üniversitesi, Afyon.

[25] Koca, M. (2011). Bazı Mineral Malzemelerin Fren Balatalarında Sürtünme Özelliklerinin Araştırılması. Yüksek Lisans Tezi, Afyon Kocatepe Üniversitesi, Afyon.

[26] Lee, J-J., Lee, J-A., Kwon, S., Kim, J-J. (2018). Effect of different reinforcement materials on the formation of secondary plateaus and friction properties in friction materials for automobiles. Tribology International, 120:70-9.

[27] Kocabaş, I. (2012). Kompozit Malzemelerin Fren Balatalarında Kullanılabilirliğinin ve Frenleme Performansının Araştırılması. Yüksek Lisans Tezi, Fırat Üniversitesi, Elazığ.

[28] Ikpambese, K., Gundu, D., Tuleun, L. (2016). Evaluation of palm kernel fibers (PKFs) for production of asbestos-free automotive brake pads. Journal of King Saud University-Engineering Sciences, 28(1):110-8.

[29] Arman, M., Singhal, S., Chopra, P., Sarkar, M. (2018). A review on material and wear analysis of automotive Break Pad. Materials Today: Proceedings, 5(14):28305-12.

[30] Binda, F. F., de Alvarenga Oliveira, V., Fortulan, C. A., Palhares, L. B., dos Santos, C. G. (2020). Friction elements based on phenolic resin and slate powder. Journal of $\mathrm{Ma}$ terials Research and Technology, 9(3): 3378-3383.

[31] Taşyürek, M., Aras, S. (2020). Assessment of Mechanical and Thermal Properties of Juniperus Drupacea/Epoxy Biocomposite. International Journal of Engineering Research and Development, 12(1): 21-31.

[32] Sait, A., Tarakçıŏlu, N. (2019). Experimental investigation of the effect of compression pressure on mechanical properties in glass fiber reinforced organic material-based brake pads production. International Advanced Researches and Engineering Journal, 3(2):111-5.

[33] Belrhiti, Y., Dupre, J., Pop, O., Germaneau, A., Doumalin, P., Huger, M., et al. (2017). Combination of Brazilian test and digital image correlation for mechanical characterization of refractory materials. Journal of the European Ceramic Society, (5): 2285-93.

[34] Dai, Y., Li, Y., Xu, X., Zhu, Q., Yan, W., Jin, S., et al. (2019). Fracture behaviour of magnesia refractory materials in tension with the Brazilian test. Journal of the European Ceramic Society, 39(16): 5433-41.

[35] Proveti, J. R. C., Michot, G. (2006). The Brazilian test: a tool for measuring the toughness of a material and its brittle to ductile transition. International Journal of Fracture, 139(34): $455-60$

[36] Fairhurst, C. (1964). On the validity of the 'Brazilian'test for brittle materials. In International Journal of Rock Mechanics and Mining Sciences \& Geomechanics Abstracts, 1(4): 535-546.

[37] Li, D., Wong, L. N. Y. (2013). The Brazilian disc test for rock mechanics applications: review and new insights. Rock Mechanics and Rock Engineering, 46(2): 269-87.

[38] Arjmand M., Shojaei A. (2011). Tribological characteristics of rubber-based friction materials. Tribology Letters. 41(2): 325-36.

[39] Gutierrez-Gonzalez C.F., Smirnov A., Centeno A., Fernández A., Alonso B., Rocha V.G., et al. (2015). Wear behavior of graphene/alumina composite. Ceramics International. 41(6): 7434-8.

[40] Saffar A., Shojaei A., Arjmand M. (2010). Theoretical and experimental analysis of the thermal, fade and wear characteristics of rubber-based composite friction materials. Wear. 269(1-2): 145-51.

[41] Zhang L., Gong H. (2015). A cheap and non-destructive approach to increase coverage/loading of hydrophilic hydroxide on hydrophobic carbon for lightweight and high-performance supercapacitors. Scientific Reports. 5(1):1-11.

[42] Akinci, I., Ozdemir, F., Topuz, A., Kabas, O., Canakc,i M. (2004). Some physical and nutritional properties of Juniperus drupacea fruits. Journal of Food Engineering, 65(3): 325-31.

[43] Hendre, K., Bachchhav, B. (2020). Tribological behaviour of non-asbestos brake pad material. Materials Today: Proceedings, 38, 2549-2554.

[44] Moses, A. J., Babu, A. S., Kumar, S. A. (2020). Analysis of physical properties and wear behavior of phenol formaldehyde-Basalt fiber reinforced brake pad. Materials Today: Proceedings, 33:1128-32.

[45] Quinn, T. (1971). Oxidational wear. Wear, 18(5): 413-9.

[46] Natarajan, N., Vijayarangan, S., Rajendran, I. (2006). Wear behaviour of A356/25SiCp aluminium matrix composites sliding against automobile friction material. Wear, 261(78): 812-22.

[47] Aras, S. (2019). Investigation of the Use of Organic Material Based Hybrid Friction Composites in Pad Production. PhD Thesis, Selçuk University, Konya.

[48] Bashir M., Qayoum A., Saleem S.S. (2021). Experimental Investigation of Thermal and Tribological Characteristics of Brake Pad Developed from Eco-Friendly Materials. Journal of Bio-and Tribo-Corrosion. 7(2): 1-13. 